\title{
Efficient translation of poly(A)-deficient mRNAs in Saccharomyces cerevisiae
}

\author{
Aaron Proweller and Scott Butler ${ }^{1}$ \\ Department of Microbiology and Immunology, University of Rochester School of Medicine and Dentistry, Rochester, \\ New York 14642 USA
}

The polyadenylate tail of eukaryotic mRNAs is thought to influence various metabolic phenomena including mRNA stability, translation initiation, and nucleo-cytoplasmic transport. We have analyzed the fate of mRNAs following inactivation of poly(A) polymerase in Saccharomyces cerevisiae containing a temperature-sensitive, lethal mutation (pap 1-1) in the gene for poly(A) polymerase (PAP1). Inactivation of poly(A) polymerase (Pap1) by shifting cells to the nonpermissive temperature resulted in the loss of at least $80 \%$ of measurable poly(A) within 60 min. Northern blot analysis revealed the disappearance of some mRNAs (CYH2 and HIS4) consistent with a role for poly(A) tails in mRNA stability. However, other mRNAs (TCM1, $P A B 1, A C T 1$, and $H T B 2)$ accumulate as poly(A)-deficient $(A<\sim 25)$ transcripts as defined by an inability to bind oligo(dT)-cellulose. Sucrose density gradient analysis of polyribosomes revealed a twofold reduction in the amount of each size class of polyribosomes in shifted cells and a commensurate increase in free ribosomes. However, poly(A)-deficient $\mathrm{mRNAs}$ in shifted cells remain associated with the same size polyribosomes as poly $(\mathbf{A})^{+}$mRNAs in unshifted cells, indicating normal initiation of translation. RNase mapping of transcripts from pap1-1 cells revealed $P A B 1$ mRNA to be poly(A) ${ }^{-}$whereas TCM1 exists as equal amounts of poly $(A)^{-}$and poly $(A)^{+}$mRNA 60 min after shift. Interestingly, both of these classes of TCM1 mRNA appear in similar amounts in each polyribosome fraction indicating that ribosomes may not distinguish between them. These findings suggest that under conditions of excess translational capacity, $\operatorname{poly}(A)^{-}$and $\operatorname{poly}(A)^{+}$mRNAs may initiate translation with comparable efficiencies.

[Key Words: Polyadenylation; protein synthesis; mRNA stability; polyribosomes]

Received June 28, 1994; revised version accepted September 18, 1994.

Almost 20 years after the physical characterization of the poly(A) tail at the 3 ' end of mature eukaryotic mRNAs, the function or functions imparted by this feature remain unclear. Much of the debate concerns the possible role of poly(A) in mRNA stability, protein synthesis, and nuclear export (Brawerman 1981). In particular, posttranscriptional modifications of most eukaryotic mRNA impart structural features thought to operate as translational enhancers and include the addition of a $5^{\prime}-\mathrm{m}^{7} \mathrm{G}$ cap and a $3^{\prime}$-poly(A) tail (Jackson and Standart 1990; Munroe and Jacobson 1990; Gallie 1991; Jackson 1993). However, a mechanistic understanding of these observations remains elusive. With the advent of in vitro-synthesized mRNA it became possible to engineer RNA with poly(A) tails of defined length, and the subsequent injection of these mRNAs into amphibian or mammalian oocytes created a unique opportunity to study both the chemical (i.e., stability) and functional (i.e., synthesis of translation product) half-lives of the mRNAs. Deadenylated RNA microinjected into Xenopus oocytes had similar chemical half-lives compared to their poly $(\mathrm{A})^{+}$forms, and only after $24 \mathrm{hr}$ did the poly $(\mathrm{A})^{-}$,

${ }^{1}$ Corresponding author. but not poly $(\mathrm{A})^{+}$forms mRNA rapidly degrade (Galili et al. 1988). However, the poly(A) tail appeared to enhance protein synthesis independent of effects on mRNA stability, although deadenylated mRNA was translated with $50 \%$ efficiency relative to poly $(\mathrm{A})^{+}$mRNA in these experiments, suggesting that a pathway exists for the translation of poly(A) ${ }^{-}$mRNAs (Drummond et al. 1985; Galili et al. 1988; Gallie 1991).

Developmental studies of clam, frog, and mouse oocytes perhaps best exemplify the effect of poly(A) tails on translation by revealing a dependence on poly $(\mathrm{A})$ tails for recruitment of translationally dormant mRNAs into polyribosomes (Richter 1991; Bachvrova 1992; Wickens 1992). Furthermore, heat shock effects in Drosophila melanogaster embryos include alterations in poly(A) tail lengths that correlate with translational efficiency (Storti et al. 1980). In contrast, deadenylation of specific RNAs can result in an increase in translatability as shown during early Xenopus embryogenesis, when deadenylation of histone mRNA actually facilitates translation activation of core histone messages (Ballantine and Woodland 1985).

Evidence for a role for poly(A) in translation comes from recent studies implicating poly(A)-binding protein 
(PABP) in translation initiation. Specifically, a yeast strain depleted of PABP resulted in a polyribosome profile suggestive of an initiation defect, and a mutation in ribosomal protein L46 (rpL46) could suppress the abnormality (Sachs and Davis 1989). Because PABP binds to poly(A), as well as other homoribonucleotide polymers, it was proposed that $P A B P$ exerted its function in protein synthesis through binding to the poly(A) tail (Bernstein et al. 1989; Sachs and Davis 1989; Burd et al. 1991). Support for this role came from studies showing that addition of PABP to a translation system in vitro could relieve the inhibition of translation of poly $(\mathrm{A})^{+}$RNAs by exogenous poly(A) (Jacobson and Favreau 1983; Lemay and Milward 1986; Grossi da Sa et al. 1988). In this respect, the poly $(A)$ tail would presumably mediate PABP function.

We reported previously that protein synthesis continues after inactivation of a temperature-sensitive poly $(\mathrm{A})$ polymerase despite significant loss in $\operatorname{poly}(\mathrm{A})$ content (Patel and Butler 1992). Specifically, the rate of $\left[{ }^{35} \mathrm{~S}\right.$ ) methionine incorporation into protein remained nearly unchanged long after poly(A) levels had fallen to undetectable levels. This finding suggested that translation may not require poly(A) tails and prompted further investigation. We designed the experiments presented here to determine whether translation in poly(A)-deficient cells results from initiation by a subset of polyadenylated $\mathrm{mR}$ NAs, or whether poly $(A)^{-}$mRNAs may be translated normally. Our findings, based in part on the similarity of polyribosome profiles and mRNA distribution, suggest that poly(A)- mRNAs may indeed initiate translation as efficiently as poly $(\mathrm{A})^{+}$transcripts. Finally, we discuss the significance of these findings in light of evidence that poly(A) tail length plays a critical role in the efficiency of translation initiation.

\section{Results}

Stability and poly $(A)$ status of $m R N A$ after inactivation of poly $(A)$ polymerase in shifted pap1-1 cells

Previous experiments from our laboratory showing that thermal inactivation of $\operatorname{poly}(\mathrm{A})$ polymerase in vivo in a pap1-1 strain led to diminished levels of poly|A) were based on a poly(A) content assay involving protection of poly(A) from RNase A digestion (Patel and Butler 1992). Although informative for quantitation of poly(A) tail loss, there remained several questions including the relative fate of global and specific mRNAs as well as their poly(A) tail status. To address these concerns, we determined the average poly(A) tail length of total RNA present in cells by labeling the 3' ends of total RNA with $\left[5^{\prime}-{ }^{32} \mathrm{P}\right] \mathrm{pCp}$, followed by RNase $\mathrm{T} 1$ and $\mathrm{A}$ hydrolysis, and subsequent separation of nuclease resistant poly(A) by polyacrylamide electrophoresis. Figure 1 illustrates the result of such an experiment and shows a significant reduction in the amount and overall size of poly(A) tracts (A $>10$ nucleotides) after shifting a pap1-1 strain to $35^{\circ} \mathrm{C}$ for $60 \mathrm{~min}$. Laser scanning densitometry revealed that poly $(A)$ disappears with kinetics similar to that of total

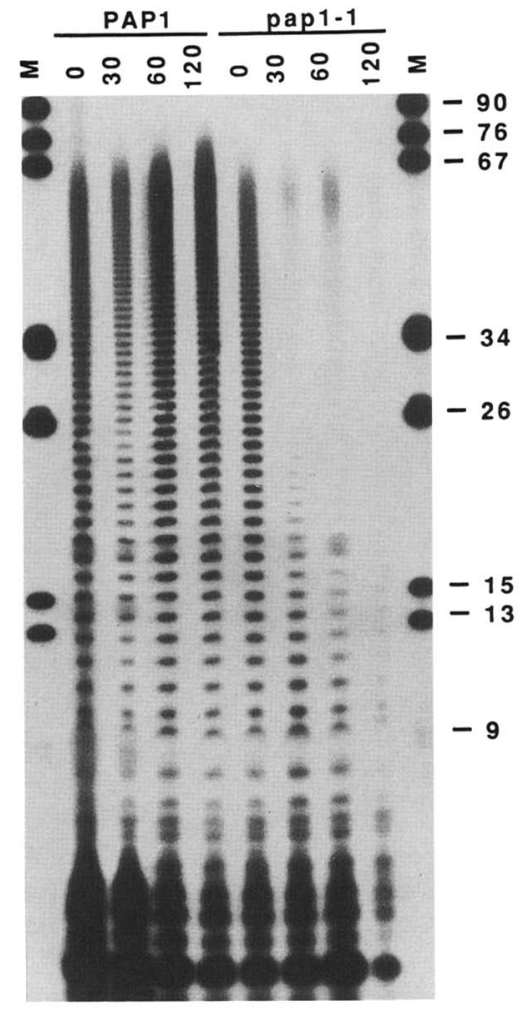

Figure 1. Amounts and lengths of poly $(\mathrm{A})$ tails in a PAP1 and a pap1-1 strain after shift to $35^{\circ} \mathrm{C}$. Cells were grown and shifted to $35^{\circ} \mathrm{C}$ for the amount of time indicated, and total RNA was prepared from equal numbers of cells. Equal amounts of total RNA were $3^{\prime}$-end labeled with RNA ligase and $\left[5^{\prime}-{ }^{32} \mathrm{P}\right] \mathrm{pCp}$. The specific activity of each sample was determined and samples were used only when their specific activities differed by $<20 \%$. Equal amounts of RNA were hydrolyzed with RNases A and T1, and the resistant poly(A) tracts were separated by denaturing polyacrylamide gel electrophoresis and visualized by radioautography. Quantities of products discussed in the text were determined by laser scanning densitometry and are the average of two independent experiments.

mRNA $\left(t_{1 / 2}=20\right.$ min; Hynes and Phillips 1976) suggesting rapid inactivation of poly(A) polymerase after temperature shift. Moreover, this experiment reveals loss of $>80 \%$ of cellular poly (A) by $60 \mathrm{~min}$ after shift to the nonpermissive temperature. Of the poly $(\mathrm{A})^{+}$RNA remaining at this time, about one-third carries poly(A) tracts in the range of 50-60 residues, possibly resulting from residual poly(A) polymerase activity.

Poly(A) tails apparently play a crucial role in controlling mRNA chemical stability (Muhlrad and Parker 1992; Decker and Parker 1993; Lowell et al. 1993). Accordingly, we determined by Northern blot analysis the amounts of several mRNAs after inactivation of poly(A) polymerase. Consistent with this function, polyadenylation shut off immediately results in a decrease in the amount of all species monitored (Fig. 2A), whereas shift of normal cells to $35^{\circ} \mathrm{C}$ has little if any effect on mRNA levels (Patel and Butler 1992; data not shown). Although 
A

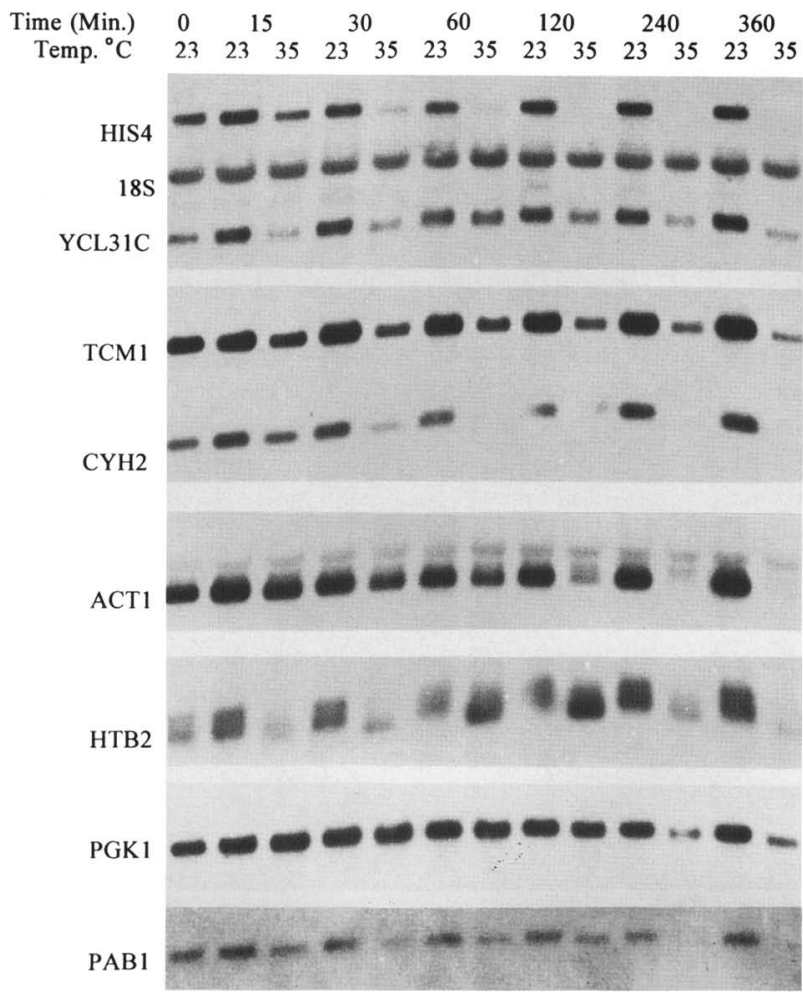

B

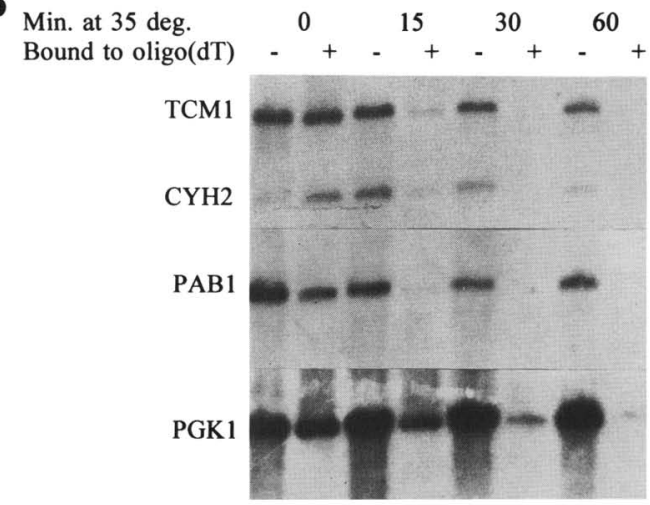

Figure 2. Amounts and polyadenylation status of specific mRNAs after inactivation of Pap1. (A) Accumulation of various mRNAs in a pap1-1 strain as a function of time at $23^{\circ} \mathrm{C}$ or $35^{\circ} \mathrm{C}$. Cells were grown at $23^{\circ} \mathrm{C}$, and at time zero, the culture was split and half remained at $23^{\circ} \mathrm{C}$ while the other half was incubated at $35^{\circ} \mathrm{C}$. Equal numbers of cells were harvested at the times indicated and total RNA was prepared (Patel and Butler 1992). mRNA levels were determined by Northern blot analysis of equal amounts of total RNA. $(B)$ Polyadenylation status of TCM1, CYH2, PAB1, and PGK1 mRNAs as a function of time after shift of a pap1-1 strain to $35^{\circ} \mathrm{C}$. Total RNA was separated into poly $(\mathrm{A})^{+}$and poly(A)-deficient RNA by oligo(dT)-cellulose chromatography and the amounts of each fraction determined by Northern blot analysis (Patel and Butler 1992).

some mRNAs (CYH2 and HIS4) disappear, others continue to accumulate (TCM1, PAB1, HTB2, YCL31C, and $A C T 1$ ) or reaccumulate until between 2 and $4 \mathrm{hr}$ after shift when the cells stop growing (Patel and Butler 1992). This pattern of mRNA levels coincides with an increase in the rate of RNA synthesis under these conditions (data not shown), suggesting that an increase in transcription may, in some cases, compensate for the instability of poly(A)-deficient mRNAs causing them to accumulate. Alternatively, the mRNAs detected at $60 \mathrm{~min}$ after inactivation of poly(A) polymerase may persist as, or become, poly $\mid \mathrm{A})^{+}$by some unanticipated mechanism. The results shown in Figure $2 B$, however, indicate that the majority of TCM1,CYH2, PAB1, and PGK1 transcripts detected $60 \mathrm{~min}$ after shift do not bind to oligo(dT)-cellulose and so have very short, or no poly(A) tails (Groner et al. 1974; Patel and Butler 1992).

\section{Protein synthesis in poly $(A)$-deficient cells}

We previously measured the rate of translation in pap1-1 cells by a pulse-labeling procedure and found that the rate of translation in pap1-1 cells, although slower than in PAP1 cells, did not change significantly for up to $2 \mathrm{hr}$ after shift to $35^{\circ} \mathrm{C}$, despite a dramatic loss of cellular poly(A) (Patel and Butler 1992). This finding contrasted with many observations indicating an important role for poly $(A)$ in the initiation of protein synthesis and prompted us to determine the effect of polyadenylation shutoff on protein synthesis in growing cells by an alternative, continuous labeling procedure. The result (Fig. 3) shows nearly linear incorporation of $\left[{ }^{35}\right.$ S $]$ methionine (normalized to the -30 min values) into protein in a

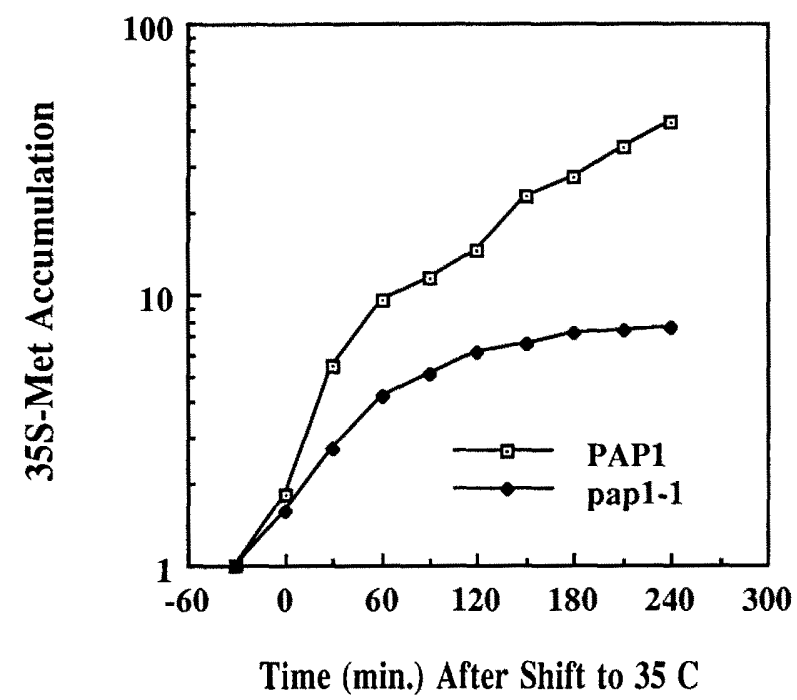

Figure 3. Protein synthesis in a PAP1 and a pap1-1 strain before and after shift to $35^{\circ} \mathrm{C}$. Cells were grown in YPD at $25^{\circ} \mathrm{C}$ to a density of $1 \times 10^{6}$ to $2 \times 10^{6} \mathrm{cell} / \mathrm{ml}$ and labeled at $-60 \mathrm{~min}$ with $0.1 \mathrm{mCi}$ of $\left[{ }^{35} \mathrm{~S}\right]$ methionine $(1140 \mathrm{Ci} / \mathrm{mmole})$ in $10 \mathrm{ml}$ of the same media. Aliquots of $0.5 \mathrm{ml}$ were withdrawn at the indicated times, and incorporation into protein was determined by the hot TCA assay. The data shown represent the average of two determinations and have been normalized to the $-30 \mathrm{~min}$ before shift value $\left(5 \times 10^{3}\right.$ to $7 \times 10^{3} \mathrm{cpm}$ for each strain). 
PAP1 strain for up to $4 \mathrm{hr}$ after shift to $35^{\circ} \mathrm{C}$. A pap1-1 strain, on the other hand, shows linear incorporation at a rate about one-half that of $P A P 1$, until $60-90 \mathrm{~min}$ after shift, followed by a decrease in the amount of protein made over the next $90 \mathrm{~min}$. This experiment indicates that although the amount of protein made after inactivation of poly(A) polymerase accumulates more slowly than that made in a normal PAP1 cell, a significant amount of protein synthesis occurs during the time 10 $60 \mathrm{~min}$ after shift) when $80 \%$ of the poly(A) disappears from pap1-1 cells. We considered two alternative explanations for these results: (1) The slowdown in protein synthesis reflects a reduced rate of translation initiation due to the loss of poly(A) tails from mRNAs; or (2) the decrease in protein synthesis results from a reduction in the amount of mRNA available for protein synthesis as suggested from the results in Figure 2A.

\section{Polyribosome profiles from papl-1 cells reveal reduced protein synthesis without a defect in translation initiation}

A decrease in the rate of translation initiation should (1) reduce the number of large polyribosomes more than small ones and (2) cause poly(A)-deficient mRNAs to shift to smaller polyribosomes. To test this prediction, we prepared whole-cell lysates after inhibiting translation elongation with cycloheximide and analyzed polyribosome profiles by sedimentation on low salt sucrose gradients. Figure 4A shows typical polyribosome profiles from shifted and unshifted PAP1 and pap1-1 cells. $P A P 1$ cells shifted to $35^{\circ} \mathrm{C}$ undergo a $17 \pm 10 \%(n=4)$ decrease in the number of polyribosomes, perhaps because of a heat shock effect in this strain. However, pap1-1 cells show a $56 \pm 6 \%(n=4)$ reduction in the number of polyribosomes and a concomitant increase in the $80 \mathrm{~S}$ peak (Fig. 4A). The increased number of $80 \mathrm{~S}$ subunits consisted of inactive (nontranslating) $80 \mathrm{~S}$ subunits because inclusion of high salt in the lysate and sucrose gradient just prior to sedimentation resulted in the resolution of the $80 \mathrm{~S}$ ribosomes into 60S and 40S subunits (Martin 1973; data not shown). The pap1-1 profile at $35^{\circ} \mathrm{C}$ does not reveal a shift from large to smaller size polyribosomes typical of translation initiation defects. Instead, the small and intermediate-size polyribosomes (fractions 2-5) decrease proportionately when compared with unshifted and normal cells, whereas the largest polyribosomes (fractions 1-2) decrease far less.

We characterized further the fate of TCM1, PAB1, and PGK1 poly(A)-deficient mRNAs along the pap1-1 polyribosome gradient by determining the quantity of these mRNAs in each gradient fraction before and after temperature shift. We specifically chose TCM1 and PAB1 mRNAs because of (1) their relative abundance at $60 \mathrm{~min}$ after shift to $35^{\circ} \mathrm{C},(2)$ their short half-lives ( $\leqslant 11 \mathrm{~min}$ ), which allows the detection of messages largely synthesized after the inactivation of poly(A) polymerase, and (3) their length (>1200 nucleotides), which upon an initiation defect, should allow them to move from large to small polyribosomes. Figure $4 \mathrm{~B}$ shows the distribution of each mRNA among the different sized polyribosomes. As expected, shifting a $P A P 1$ strain from $25^{\circ} \mathrm{C}$ to $35^{\circ} \mathrm{C}$ resulted in no change in the number of ribosomes translating each mRNA (data not shown). Translation of poly(A)-deficient mRNAs in pap1-1 cells shifted to $35^{\circ} \mathrm{C}$ for $1 \mathrm{hr}$ does not occur on smaller polyribosomes as expected for an initiation defect. Instead, these mRNAs appear associated with more ribosomes, on average, than in unshifted cells. These findings suggest that poly(A)deficient mRNAs may initiate translation as well, or somewhat better than poly $(A)^{+}$mRNAs in normal, and unshifted pap1-1 cells. Part of this surprising effect may result from an increase in the ratio of free ribosomes to mRNA caused by the loss of many mRNA species after polyadenylation shutoff. These findings suggest that although the amount of protein synthesis in poly(A)-deficient cells falls twofold because of a decrease in the quantity of mRNA, the rate of translation of poly(A)deficient mRNAs remains similar to that of $\operatorname{poly}(A)^{+}$ mRNAs in unshifted and normal cells.

\section{Pap1 inactivation produces poly $(A)^{-} \mathrm{PAB} 1$} and $\mathrm{TCM} \mathrm{mRNAs}$

We designated the mRNAs studied here as poly(A)-deficient on the basis of their inability to bind to oligo(dT)cellulose: This matrix does not retain mRNAs with poly(A) tails of less than $\sim 15$ residues (Groner et al. 1974; Fig. 2B). Because poly(A)-binding protein may interact with poly(A) tracts as small as 12 nucleotides and because this protein appears to mediate the role of poly $(\mathrm{A})$ in translation initiation, we sought a method to determine whether these mRNAs might have short poly(A) tails that enhance their translation. We designed an RNase protection assay to determine the amount of a specific mRNA as well as its poly(A) tail length. First, we mapped the polyadenylation sites of $P A B 1$ and TCM1 mRNAs by use of a reverse transcriptase-PCR (RTPCR/-based approach that produces specific CDNAs carrying the first 17 adenosine residues of the poly(A) tail (Sadhale et al. 1991). For PAB1 this produces a major cDNA of $\sim 300$ nucleotides from normal and unshifted pap1-1 cells, which disappears from shifted pap1-1 cells (Fig. 5A). After cloning into transcription vectors these cDNAs can produce RNA probes capable of distinguishing poly $(\mathrm{A})^{-} \mathrm{mRNAs}$ from those with very short tails. DNA sequence analysis of 16 independent $\mathrm{cDNA}$ clones of $P A B 1$ revealed a major poly(A) site (10 of 16 clones) and three minor poly(A) sites (Fig. 5B). None of these sites corresponds to that previously mapped for $P A B 1$ (Sachs et al. 1986); however, the two minor poly(A) sites $3^{\prime}$ distal to the major poly(A) site appeared twice and only once, respectively, in the 16 clones, suggesting that sequencing more clones might reveal additional minor sites, including that mapped previously. Because we have shown previously the RT-PCR method to be more reliable than S1 nuclease analysis of mRNA 3 ' ends (Sadhale et al. 1990), and because RNase protection analysis 

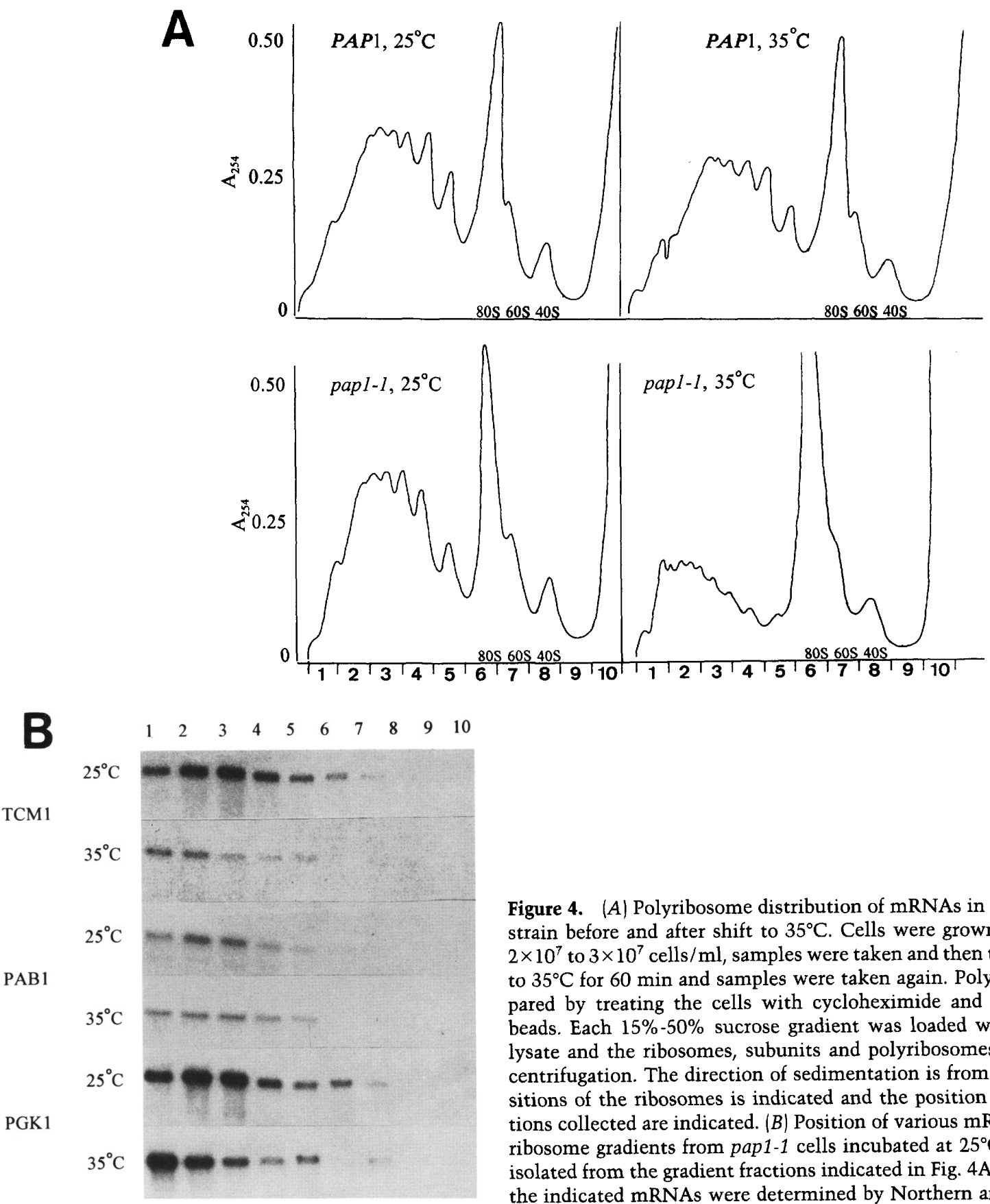

Figure 4. (A) Polyribosome distribution of mRNAs in a PAP1 and a pap1-1 strain before and after shift to $35^{\circ} \mathrm{C}$. Cells were grown in YPD at $25^{\circ} \mathrm{C}$ to $2 \times 10^{7}$ to $3 \times 10^{7}$ cells $/ \mathrm{ml}$, samples were taken and then the cells were shifted to $35^{\circ} \mathrm{C}$ for $60 \mathrm{~min}$ and samples were taken again. Polyribosomes were prepared by treating the cells with cycloheximide and breaking with glass beads. Each $15 \%-50 \%$ sucrose gradient was loaded with $25 A_{254}$ units of lysate and the ribosomes, subunits and polyribosomes separated by ultracentrifugation. The direction of sedimentation is from right to left, the positions of the ribosomes is indicated and the position of the gradient fractions collected are indicated. $(B)$ Position of various mRNAs along the polyribosome gradients from pap 1-1 cells incubated at $25^{\circ} \mathrm{C}$ or $35^{\circ} \mathrm{C}$. RNA was isolated from the gradient fractions indicated in Fig. 4A, and the amounts of the indicated mRNAs were determined by Northern analysis.

(see below) confirms the usage of the two most prevalent sites ( $\mathrm{M}$ and $\mathrm{ml}$, Fig. $5 \mathrm{~B})$, we consider them correct. RNase protection analysis with the major poly(A) site $M$ cDNA probe and RNA from normal and unshifted pap 1-1 cells yielded 3 products (Fig. 5C, lanes $3-5$ ). The largest ( 190-nucleotide) diffuse product results from protection by mRNAs polyadenylated at the major poly(A) site, $M$, whereas the smallest product corresponds to protection by mRNAs ending at the $5^{\prime}$ minor site, $\mathrm{ml}$. The $\sim 170$-nucleotide product results from protection of the probe up to the major poly(A) site, $M$, by
mRNAs ending at this site and, or those extending past it. Messages producing this product are the only ones present after inactivation of Pap1, suggesting that they may be major site poly(A)-mRNAs (Fig. 5C, lane 6). If this product results from protection by the major site poly(A)-mRNA rather than by mRNAs extending past this site, then it should remain in protection experiments featuring a probe extending to a $3^{\prime} \operatorname{distal}$ poly $(\mathrm{A})$ site, whereas messages polyadenylated at or ending at $3^{\prime}$ distal sites should yield longer protection products with such a probe. Protection of a probe derived from the $3^{\prime}$ 
A

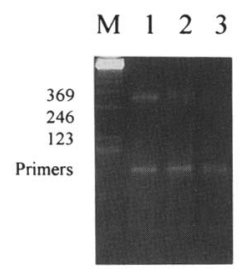

B

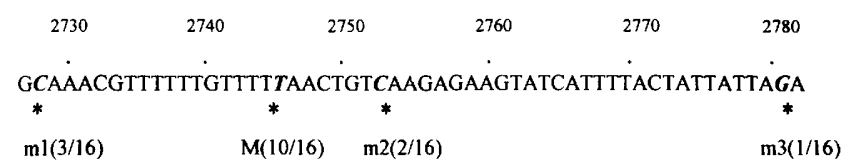

Figure 5. Determination of $P A B 1$ poly(A) tail lengths. (A) RTPCR synthesis of cDNAs spanning the poly(A) site of $P A B 1$ mRNA from (Lane M) 123-bp molecular size markers (GIBCO-BRL); (lane 1) PAP1 cells at $25^{\circ} \mathrm{C}$; (lane 2) pap1-1 cells at $25^{\circ} \mathrm{C}$; (lane 3) pap1-1 cells at $25^{\circ} \mathrm{C}$ for $60 \mathrm{~min}$. (B) DNA sequence of the sense strand in the polyadenylation region of $P A B 1$. Numbering above follows that of Sachs et al. (1986); bold letters with an asterisk (*) beneath indicate sites of polyadenylation determined by cDNA sequence analysis. All of the cDNAs extending past the major poly(A) site $\mathrm{M}$ had only $5 \mathrm{~T}$ residues (positions 2741-2745), rather than the $6 \mathrm{~T}$ residues in the published sequence (Sachs et al. 1986). The values in parentheses indicate the number of clones out of the 16 sequenced that were polyadenylated at that site. $(C)$ Ribonuclease protection assay of PAB1 mRNAs. (Lane M) DNA molecular size markers (22 P-labeled MspI fragments of pBR322) with lengths indicated at left. RNase protection of the major poly(A) site probe (lanes 1-6) and the $3^{\prime}$ distal poly(A) site probe (lanes 7-12). No RNase treatment (lanes $1,7)$. RNase protection with $10 \mu \mathrm{g}$ of $E$. coli tRNA (lanes 2,8$), 10 \mu \mathrm{g}$ of $P A P 1 \mathrm{RNA}\left(25^{\circ} \mathrm{C}\right)$ (lanes 3,9$) ; 10 \mu \mathrm{g}$ of $P A P 1 \mathrm{RNA}\left(35^{\circ} \mathrm{C}, 60 \mathrm{~min}\right)$ (lanes 4,10$), 10 \mu \mathrm{g}$ of pap1-1 RNA $\left(25^{\circ} \mathrm{C}\right)$ (lanes 5,11$), 10 \mu \mathrm{g}$ of pap1-1 RNA $\left(35^{\circ} \mathrm{C}, 60 \mathrm{~min}\right)$ (lanes 6,12$)$. The positions of protection products corresponding to the $P A B 1$ poly(A) sites are indicated at right. The major site $\mathrm{M}$ probe used in lanes 1-6 contains 162 nucleotides from the DdeI site in PAB1 (position 2582) to the M poly(A) site, $17 \mathrm{U}$ residues and 42 nucleotides of vector sequence. The $3^{\prime}$ distal m3 probe used in lanes 7-9 contains 199 nucleotides of sequence from the DdeI in PAB1 to the m3 poly(A) site, $17 \mathrm{U}$ residues, and 42 nucleotides of vector sequence. $(D)$ Effect of RNase dilution on RNase protection products. RNase stock $(0.28 \mathrm{mg} / \mathrm{ml}$ of RNase A; $20 \mu \mathrm{g} / \mathrm{ml}$ of RNase T1) was diluted as indicated, and the protection experiment was carried out on RNA from pap1-1 cells grown at $25^{\circ} \mathrm{C}\left(-1\right.$, or shifted to $35^{\circ} \mathrm{C}(+)$ as indicated. (Left) DNA molecular size markers and DNA sequencing lanes from an unrelated template for length determinations. Experiments in $C$ and Figs. 6C and 7 were carried out using the 1:200 RNase stock dilution.

distal poly(A) site m3 cDNA (Fig. 5B) by RNA from shifted pap1-1 cells yields only the $\sim 170$-nucleotide product, indicating that the majority of $P A B 1$ mRNAs end at the major poly(A) site $M, 60$ min after Papl inactivation (Fig. 5C, lane 12). Because none of these mRNAs protect the poly(A) derived portion of the major site probe to yield the $\sim 190$-nucleotide product, they must be poly(A) (Fig. 5C, cf. lanes 6 and 12).

The unexpected production of the $\sim 170$-nucleotide product by protection of the $3^{\prime}$ distal probe with mRNA from normal and unshifted pap1-1 cells suggested that poly $(\mathrm{A})^{-} P A B 1$ mRNAs might exist under these conditions (Fig. 5C, lanes 9-11). However, close inspection of these products revealed that they are slightly longer than the 170-nucleotide products in lanes 3-6 and lane 12 of Figure 5C. Moreover, we found that increasing the RNase concentration shortened these slightly longer products to the same size as those from shifted cells, whereas the $\mathrm{ml}$ and the 170-nucleotide products from shifted cells remain the same size (Fig. 5D). We suggest that this behavior results from the fact that the probe contains two U residues (nucleotides 2747-2748) capable of protecting the poly(A) tail added at site $\mathrm{M}$ and three $\mathrm{U}$ residues (nucleotides 2729-2731) capable of protecting the poly(A) tail added at site $\mathrm{ml}$ (Fig. 5A). The ends of the hybrids thus formed at $\mathrm{ml}$ will be more stable (more resistant to RNase) by virtue of two adjacent G-C base pairs compared to hybrids formed at $\mathrm{M}$, which lie adjacent to 5 A-U base pairs. The specificities of RNases A and $\mathrm{Tl}$ dictate that they will not cleave the probe in the run of 5 As preceding the poly(A) site $M$, causing hybrids to poly $(A)^{-}$mRNAs ending at $M$ to appear stable at higher concentrations of these enzymes Thus we conclude that the RNase-sensitive products from protection of the $3^{\prime}$ distal poly(A) site probe result from protection by major site $M$ poly $(A)^{+}$mRNAs and that little, if any, poly $(\mathrm{A})^{-}$PAB1 mRNA exists in normal or unshifted pap 1-1 cells. More importantly, the results in Figure 5 show that the majority of $P A B 1$ transcripts present and translated in pap1-1 cells after shift to $35^{\circ} \mathrm{C}$ for $60 \mathrm{~min}$ do 
not carry poly(A) tails, consistent with their production after Papl inactivation.

Amplification of TCM1 mRNA with a TCM1-specific primer and an oligo(dT) primer produced a single major product from normal, unshifted pap1-1 and shifted pap1-1 cells indicating the presence of a single polyadenylated transcript in these cells (Fig. 6A). We synthesized from a transcription vector containing this cDNA, an RNA probe that has the potential to hybridize to 166 nucleotides of TCM1 mRNA 5' to its poly(A) site and to the first 17 adenosine residues of the poly(A) tail. RNase protection experiments revealed protected fragments of about 180 nucleotides in normal and unshifted pap1-1 cells indicating that the majority of TCM1 mRNA in these cells carry poly(A) tails of about 17 nucleotides or more (TCM1-A $>17$; Fig. 6C). The relative absence of protected products from transcripts with less than about 17 adenosine residues agrees with experiments indicating that short oligoadenylate (A 12 nucleotides) species ap- parently constitute the last detectable intermediates in the mRNA turnover pathway for some mRNAs (Decker and Parker 1993). RNase protection of TCM1 mRNA from pap $1-1$ cells shifted to $35^{\circ} \mathrm{C}$ for $60 \mathrm{~min}$ revealed the appearance of a product of the length expected from protection of poly(A) ${ }^{-}$TCM1 mRNA (TCM1- $\mathrm{A}_{0}$ ). Quantitation of these products by storage PhosphorImager analysis indicates that pap1-1 cells contain similar amounts of

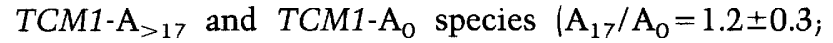
$n=5$ ) 60 min after inactivation of Papl. This finding, and the fact that neither of these species bind to oligo(dT)cellulose, supports a scenario in which inactivation of Papl results in the synthesis of poly $(A)^{-}$transcripts and the accumulation of transcripts whose poly(A) tails have been shortened to less than $\sim 25$ adenosine residues.

We investigated the possibility that the TCM1- $\mathrm{A}_{O}$ protection product might represent an artifact of the RNase protection procedure: If polyadenylation of TCM1 mRNA in shifted pap1-1 cells occurs at a different site

$\mathbf{A}$

B

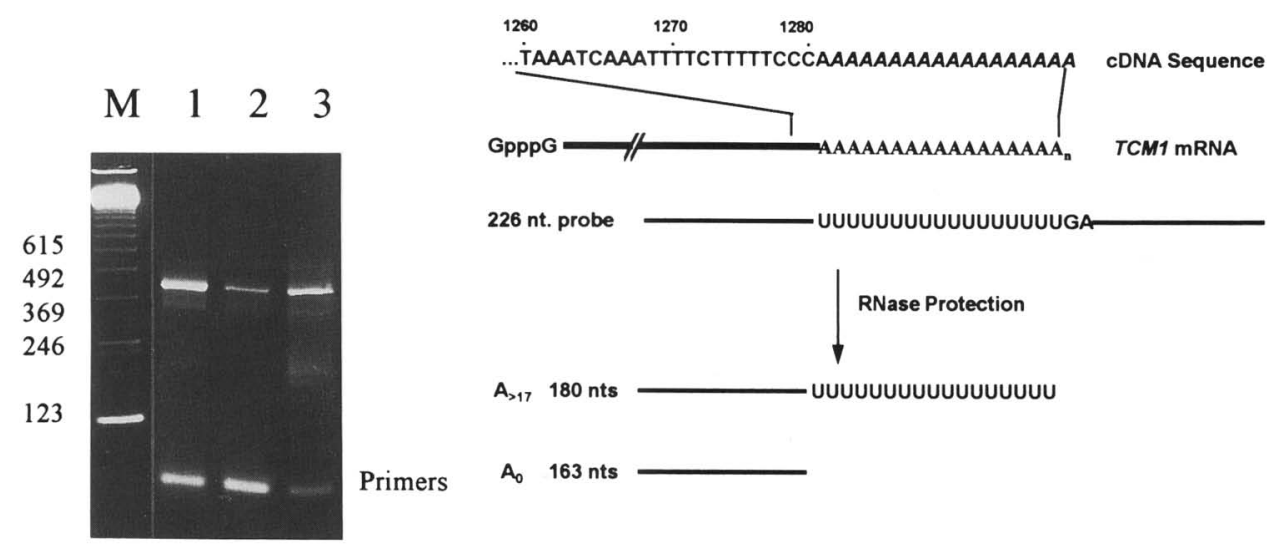

C

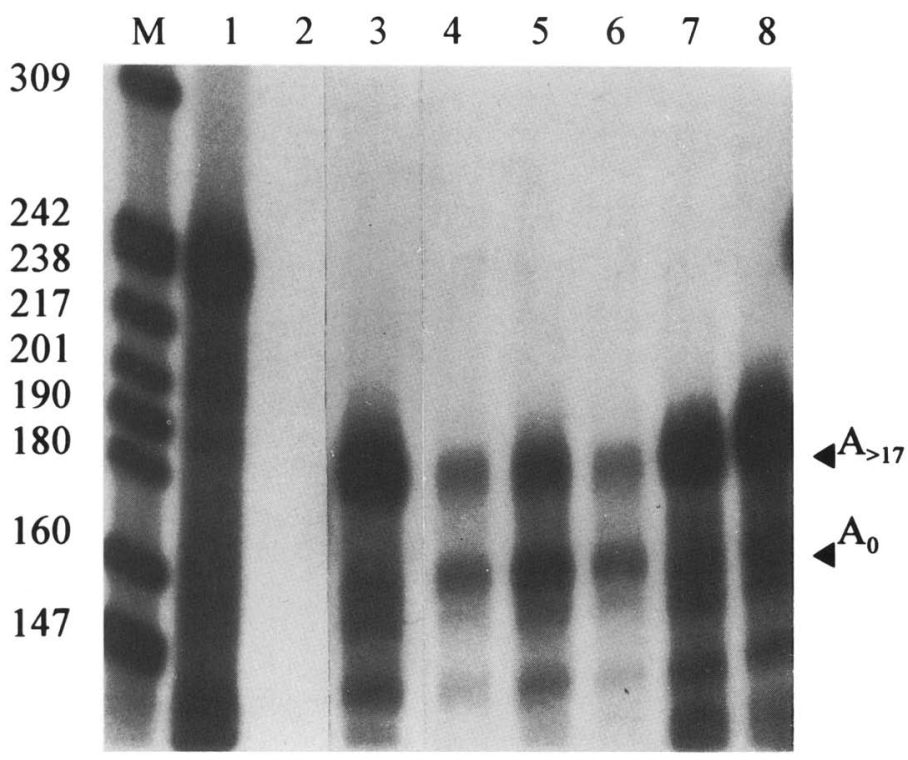

Figure 6. Determination of TCM1 poly(A) tail lengths. $|A| \mathrm{RT}-\mathrm{PCR}$ synthesis of cDNAs spanning the poly(A) site of TCM1 mRNA from: (Lane 1) pap1-1 cells at $25^{\circ} \mathrm{C}$; (lane 2) pap1-1 at $35^{\circ} \mathrm{C}$ for 60 min; (lane 3) PAP1 at $25^{\circ} \mathrm{C}$. (Lane M) 123-bp molecular size markers (GIBCO-BRL). (B) Diagram of the sequence of the TCM1 cDNA product at the polyadenylation site (nontemplate encoded nucleotides in italics), the TCM1 mRNA, the probe and expected products from the ribonuclease protection assay. $(C)$ Ribonuclease protection assay: (lane $M$ ) molecular size markers ( ${ }^{32} \mathrm{P}$-labeled $\mathrm{MspI}$ fragments of pBR322); (lane 1) untreated probe; (lane 2) probe hybridized to $10 \mu \mathrm{g}$ of $E$. coli tRNA and digested with RNase; (lane 3) probe hybridized to $10 \mu \mathrm{g}$ of pap1-1 RNA $\left(25^{\circ} \mathrm{C}\right)$ and digested with RNase; (lane 4) probe hybridized to $10 \mu \mathrm{g}$ of pap1-1 RNA $\left(35^{\circ} \mathrm{C}, 60 \mathrm{~min}\right)$ and digested with RNase; (lane 5) probe hybridized to $20 \mu \mathrm{g}$ of pap1-1 RNA $\left(35^{\circ} \mathrm{C}, 60 \mathrm{~min}\right)$ and digested with RNase (lane 6) probe hybridized to $10 \mu \mathrm{g}$ of pap1-1 RNA $\left(35^{\circ} \mathrm{C}, 60 \mathrm{~min}\right.$, independent sample) and digested with RNase; (lane 7) probe hybridized to $10 \mu \mathrm{g}$ of $P A P 1$ RNA $\left(25^{\circ} \mathrm{C}\right)$ and digested with RNase; (lane 8 ) probe hybridized to $20 \mu \mathrm{g}$ of $P A P 1$ RNA $\left(35^{\circ} \mathrm{C}, 60\right.$ min) and digested with RNase. 
than in PAP1 cells, then the riboprobe derived from TCM1 mRNA in PAP1 cells will hybridize incompletely to pap1-1 mRNA leaving internal, RNase-sensitive, mismatched bases. Indeed, DNA sequence analysis of TCM1 cDNA clones from shifted pap1-1 cells revealed that whereas 5 of 11 independent clones have the normal $\mathrm{CCCA}_{17} 3^{\prime}$ end, 6 of 11 have the end $\mathrm{CCA}_{17}$ or $\mathrm{CA}_{17}$. This polyadenylation site heterogeneity will yield hybrids during RNase protection with G-A mismatches potentially sensitive to RNase Tl, but not to RNase A. Omission of RNase Tl from the RNase protection procedure, however, had no effect on the relative yield of the TCM1- $\mathrm{A}_{>17}$ and TCM1- $\mathrm{A}_{0}$ species, indicating that the mismatches are not sensitive to the levels of RNase Tl employed in our procedure (data not shown).

\section{Ribosomes translate poly $(A)^{+}$and $\operatorname{poly}(A)^{-}$TCM1 $m R N A$ with similar efficiency}

The presence of similar amounts of poly $(A)^{-}$and poly $(\mathrm{A})^{+}$TCM1 mRNA provided a convenient test of the model that predicts that poly $(\mathrm{A})^{+}$mRNAs should initiate translation more efficiently than poly $(\mathrm{A})^{-}$mRNAs. If TCM1- $\mathrm{A}_{>17}$ mRNAs enjoy an advantage during translation initiation then they should appear on larger polyribosomes than TCM1- $\mathrm{A}_{0}$ mRNAs. Instead, the two mRNA species appear in the same proportions across the polyribosome gradient, suggesting that they initiate translation at similar rates (Fig. 7A). Polyribosomes from unshifted pap1-1 cells do not contain significant amounts of TCM1- $\mathrm{A}_{0}$ mRNA, indicating that production of this species requires inactivation of Papl (Fig. 7B). Moreover, comparison of the profile from unshifted pap1-1 cells containing predominantly poly $(\mathrm{A})^{+}$TCM1 mRNA (Fig. 7B), with that from shifted pap1-1 cells (Fig. $7 \mathrm{~A})$ reveals that $T C M 1-\mathrm{A}_{>17}$ mRNAs translate as well, or perhaps somewhat better than $\operatorname{poly}(\mathrm{A})^{+}$TCM1 mRNA.

\section{Discussion}

Our previous characterization of a thermosensitive defect in Saccharomyces cerevisiae poly(A) polymerase provided us with a unique opportunity to address directly the role of poly $(\mathrm{A})$ tails in vivo. Here we show that thermal inactivation of poly(A) polymerase results in the production of poly $(A)^{-}$mRNAs and that these mRNAs may initiate translation as well as poly $(\mathrm{A})^{+}$mRNAs. We characterized poly $(A)$ tails after inactivation of poly(A) polymerase and found (1) that the quantity of poly(A) disappears with a half-life similar to mRNA, suggesting rapid shut-off of poly(A) polymerase activity in pap1-1 after shift to $35^{\circ} \mathrm{C}$, and (2) that only $\sim 20 \%$ of cellular poly(A) remains after a 60 -min shift to the nonpermissive temperature (Fig. 1). Northern blot analysis of total RNA from pap1-1 cells revealed that inactivation of poly(A) polymerase results in the disappearance or reduction in the amount of various mRNAs (Fig. 2) consistent with a role for poly $(A)$ tails in conferring mRNA stability. The reduction in the mRNA pool correlates with the polyribosome profiles obtained from shifted pap1-1 cells
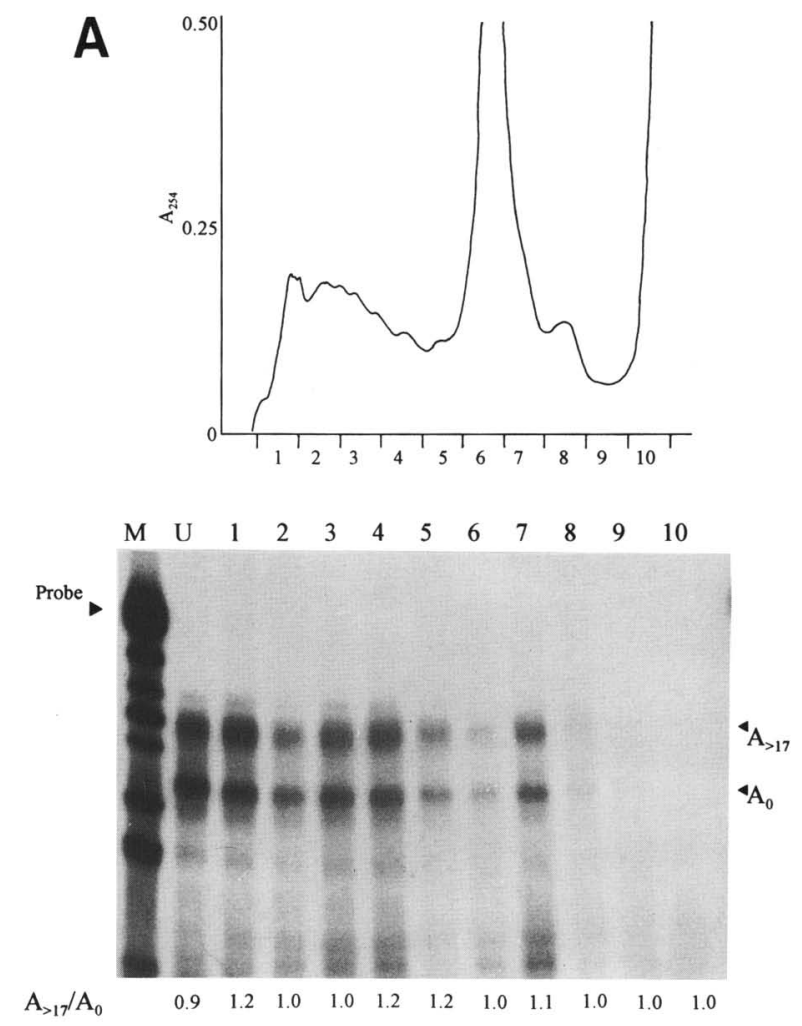

B

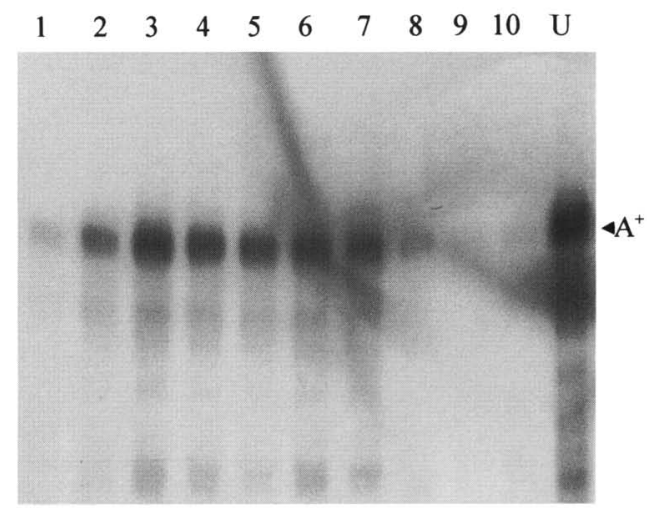

Figure 7. (A) Ribonuclease protection of polyribosomal RNA from a pap $1-1$ strain shifted to $35^{\circ} \mathrm{C}$ for $60 \mathrm{~min}$. RNA was prepared from polyribosome gradient fractions as in Fig. 4, and RNase protection was carried out on each sample as in Fig. 6. (Lane M) Molecular size markers as in Fig. 6, except that the probe was added as a reference; (lane U) unfractionated RNA; (lanes 1-10) fractions starting from the bottom of the polyribosome gradient (lane 1) to the top of the gradient (lane 10). (B) Ribonuclease protection of polyribosomal RNA from a pap1-1 strain grown at $25^{\circ} \mathrm{C}$. RNA was prepared from a polyribosome gradient similar to that shown in Fig. 4B. (Lanes 1-10) Fractions starting from the bottom of the polyribosome gradient (lane 1) to the top of the gradient (lane 10); (lane U) unfractionated RNA.

showing that these cells have approximately twofold less translating polyribosomes than unshifted cells (Fig. 4A). Significantly, all polyribosome sizes decrease propor- 
tionately and poly(A)-deficient mRNAs remain associated with large polyribosomes implying that translation initiation remains unchanged, whereas the amount of translation falls twofold. These findings contrast with polyribosome profiles from cells defective for translation initiation (Foiani et al. 1991; Yoon et al. 1992; Yoon and Donahue 1992; Zhong and Arndt 1993): In these cases the amounts of large polyribosomes decrease far more than the amounts of smaller ones. Thus, the defect in poly(A) tail synthesis results in a decrease in the quantity of mRNA and hence the amount of bulk translation falls. Finally, RNase mapping showed that PAB1 mRNA exists as a poly(A) ${ }^{-}$mRNA after inactivation of Papl. Interestingly, this poly $(A)^{-}$mRNA is translated efficiently, a result not necessarily expected if the product of the gene, $\mathrm{PABP}$, regulates it own expression by translational repression as proposed (Sachs et al. 1987). The loss of poly $(\mathrm{A})$ after Papl inactivation might lead to an excess of free $\mathrm{PABP}$, which, according to the model, should repress translation of $P A B 1$ mRNA.

RNase protection experiments showed that TCM1 mRNA exists as a nearly equimolar mixture of poly $(A)^{+}$ and poly(A) ${ }^{-}$mRNAs $60 \mathrm{~min}$ after inactivation of Papl. We may reasonably assume that the majority of these poly $(\mathrm{A})^{+}$transcripts have tail lengths between $\sim 10$ and 25 nucleotides because they do not bind to oligo(dT)cellulose. Accordingly, our finding that ribosomes do not discriminate between poly $(\mathrm{A})^{+}$and $\operatorname{poly}(\mathrm{A})^{-}$TCM1 transcripts reveals nothing about the potential advantage that mRNAs with long (A $>25$ nucelotides) poly(A) tails might enjoy in translation initiation. The size limitation (17 nucleotides) of the length of poly(A) detectable with our RNase protection probe and the inefficiency of the oligo(dT)-cellulose selection assays prevented us from examining the possibility that small quantities of $\mathrm{mR}$ NAs with long poly(A) tails might initiate translation with greater efficiencies than the species we detected here. Nevertheless, these experiments do indicate that efficient translation initiation does not require that a mRNA carry a poly(A) tail.

The striking loss of some, but not all mRNAs and the apparent reaccumulation of others remains, as yet, poorly characterized. These phenotypes and our preliminary data indicating an increase in transcription after Papl inactivation support a role for poly $(\mathrm{A})$ tails in mRNA stability, but it remains unclear why some $\mathrm{mR}$ NAs completely disappear, whereas others accumulate as poly(A) ${ }^{-}$mRNAs. If transcription of all genes increases under these conditions then the amount of each species of mRNA may reflect the dependence of its chemical stability on its poly(A) tail. Alternatively, the loss of some mRNAs may result from a decrease in specific transcriptional rates rather than an effect on chemical stability. If the stability of a class of transcripts required their translation, then a requirement for poly(A) in translation would result in rapid degradation of the poly(A) ${ }^{-}$mRNAs. In contrast, a class of messages that did not require poly $(A)$ for translation would accumulate and function normally in the cell. This seems an unlikely explanation for our observations because other findings show that inhibition of translation with drugs, or by cis-acting mutations inhibiting translation, result in no change, or an increase in mRNA stability (Baim and Sherman 1988; Herrick et al. 1990; Wisdom and Lee 1991; Beelman and Parker 1994).

Much of the insight into the role of polyadenylate tails in protein synthesis comes from experiments that monitored the fate of poly $(A)^{+}$and poly $(A)^{-}$forms of synthetically transcribed mRNAs microinjected into amphibian oocytes or mammalian cells (for review, see $\mathrm{Mu}$ nroe and Jacobson 1990; Galili et al. 1988; Gallie 1991). In general these experiments reveal a correlation between the presence of a poly(A) tail and the translational efficiency of a mRNA. A compelling case for a role for poly $(A)$ in translation emerges from studies showing that changes in polyadenylation status control the recruitment of translationally dormant mRNAs into polyribosomes during development of clam, frog, and mouse oocytes (Wickens 1992; Richter 1991). Observations in these systems demonstrated correlations between developmentally controlled addition of poly(A) tails to dormant mRNAs and translational activation, and between controlled poly(A) tail loss and translational inactivation (Rosenthal et al. 1983; McGrew et al. 1989; Vassalli et al. 1989; Varum and Wormington 1990, Sheets et al. 1994). These experimental systems all measure the translational potential of poly(A) ${ }^{-}$mRNAs in the presence of an excess of poly $(A)^{+}$message, under conditions where components of the translation system that associate with poly(A), such as PABP, may be saturated with mRNA (Zelus et al. 1989). If a poly(A) tail lends a small competitive advantage in protein synthesis relative to an identical coding message lacking poly(A), then the effect of poly(A) may be prominent in a system where components required for translation initiation, rather than mRNA, are limiting (Laskey et al. 1977). In contrast, our studies indicate that polyadenylation shutoff causes a decrease in mRNA levels that results in a significant increase in the ratio of free ribosomes to mRNA. Thus, the lack of apparent discrimination between poly $(\mathrm{A})^{+}$ and $\operatorname{poly}(\mathrm{A})^{-}$mRNAs in our system may result from the lack of competition for a normally limiting component of the translation initiation system such as initiation or elongation factors. This line of reasoning suggests that poly $(A)^{+}$and poly $(A)^{-}$mRNAs may compete for some limiting component of the translation system in the presence of normal mRNA levels in $S$. cerevisiae and implies that our findings may not necessarily contradict the conclusions from other systems where such competition prevails. Stevens and colleagues recently provided evidence that translation occurs at near normal rates in an XRN1 deletion mutant containing significant quantities of uncapped, poly(A)-deficient mRNAs (Larimer et al. 1992; Hsu and Stevens 1993). Although their experiments do not distinguish between the relative efficiency of translation of $\operatorname{poly}(\mathrm{A})^{+}$and poly $(\mathrm{A})^{-}$mRNA, the apparently normal ratio of nontranslating to translating ribosomes in $x r n 1$ cells and the lack of an apparent defect in the initiation of translation lends support to the idea that efficient translation initiation does not require 
poly(A) tails in vivo.

Translation systems in vitro have generated mixed conclusions regarding poly $(\mathrm{A})$ tail function because of intrinsic differences (both qualitative and quantitative) in translational efficiencies that occur, for example, in wheat germ versus reticulocyte lysates (Bergman and Lodish 1979a). Hence, extrapolation of specific conclusions may not allow a more general understanding of poly(A) physiology. The enhancement of protein synthesis due to poly(A) is less striking in systems in vitro than in vivo, yet the relative differences between $\operatorname{poly}(\mathrm{A})^{+}$and poly $(A)^{-}$messages appear consistent. Munroe and Jacobson (1990) utilized a nuclease-treated reticulocyte cellfree translation system to analyze the polyribosome profiles of differentially labeled poly $(A)^{+} \quad(A=68$ nucleotides) or poly $(\mathrm{A})^{-}$input mRNA. Poly $\left.\mid \mathrm{A}\right)^{-}$message appeared to initiate translation two- to threefold less efficiently in the presence of poly(A) ${ }^{+}$mRNA, suggesting that a poly $(\mathrm{A})$ tail confers some advantage during translation in vitro. Interestingly, poly $(\mathrm{A})^{+}$mRNA with about 20 A residues competed with poly $(A)^{-}$mRNA only about half as well as poly $(\mathrm{A})^{+}$mRNA with $68 \mathrm{~A}$ residues. This system, depleted of endogenous mRNA, may be comparable to our cells after inactivation of poly(A) polymerase in that neither situation saturates the translation system with mRNA. The small effects seen in the reticulocyte lysates, especially for transcripts with short poly(A) tails, and the apparent lack of discrimination in our cells may result from the excess translational capacity in these systems.

PABP found in association with the polyadenylate region of eukaryotic mRNAs appears to mediate the effect of poly(A) tails on protein synthesis and mRNA stability (Sachs et al. 1987; Bernstein et al. 1989; Munroe and Jacobson 1990; Burd et al. 1991; Decker and Parker 1993; Lowell et al. 1993). Depletion of PABP in S. cerevisiae inhibits translation as determined by polyribosome profile analysis, and a mutation in the 605 ribosomal subunit protein L46 (rpL46) suppresses the lethality of a PABP-deficient strain implying a role for PABP in translation initiation (Sachs and Davis 1989). Consistent with this interpretation, the addition of PABP relieved the inhibition of translation of poly $|\mathrm{A}|^{+}$mRNA by exogenous poly $(A)$ in vitro (Jacobson and Favreau 1983; Lemay and Milward 1986; Grossi da Sa 1988). These results provided evidence for a role for PABP in translation initiation and implied that PABP mediates the effect of poly(A) tails on mRNA. The efficient translation of poly $(A)^{-}$mRNA demonstrated in our experiments suggests that if translation initiation requires PABP bound to mRNA then it must bind to sequences within these transcripts. In this regard, the affinity of yeast PABP for sequences other than poly(A) appears potentially significant (Burd et al. 1991). It may be possible, under conditions of low poly(A) concentration, that excess PABP could bind to sequences internal to poly(A) ${ }^{-}$transcripts in a manner functionally similar to the interaction of PABP with short $(\mathrm{A}<25$ nucelotides $)$ poly(A) tails. Long poly(A) tails, however, might have the capacity to bind more molecules of PABP, possibly conferring an advan- tage during translation initiation. Alternatively, the decrease in mRNA levels we observe may result in an increase in the ratio of initiation factors to mRNA thus compensating for a decrease in PABP binding.

In summary, inactivation of poly $(\mathrm{A})$ polymerase in vivo results in the synthesis of poly $(\mathrm{A})^{-}$mRNAs that accumulate to varying degrees and appear to initiate translation with surprising efficiency. These findings support a role for poly(A) tails in influencing the stability of mRNA and suggest that poly(A) tails may function to enhance translation initiation only when the concentration of some translation factor becomes limiting.

\section{Materials and methods}

Yeast strains and media

The experiments reported here were carried out in the following strains: A364A (MATa, ade1, ade2, ura1, his7, lys2, tyr1, gal1), UR31481B (MATa, ade1/ade2, lys2, gal1?, ura3-52, pap1-1). Strains were grown in YEPD media.

\section{Poly $(A)$ tail length determination}

Total RNA $(1 \mu \mathrm{g})$ was heated for $10 \mathrm{~min}$ at $65^{\circ} \mathrm{C}$ and added to 3 $\mu l$ of ligation reaction $\operatorname{mix}[1.7 \mathrm{U} / \mu 1 \mathrm{RNA}$ ligase $(\mathrm{NEB}), 6.7 \mathrm{U} / \mu]$ RNasin (Promega), $1.7 \mu \mathrm{Ci} / \mu \mathrm{l}$ cytidine, $3^{\prime}, 5^{\prime}-\left[5^{\prime}-{ }^{32} \mathrm{P}\right]$ bisphosphate $(3000 \mathrm{Ci} / \mathrm{mmole}$, Amersham), $16.7 \mathrm{~mm}$ HEPES (pH 8.3), 3 $\mathrm{mM} \mathrm{MgCl}_{2}, 6 \%$ glycerol, $0.017 \mathrm{mM} \mathrm{rATP}, 2 \%$ DMSO] and incubated at $4^{\circ} \mathrm{C}$ for $16 \mathrm{hr}$. The reactions were diluted with $20 \mu \mathrm{l}$ of $0.3 \mathrm{M} \mathrm{NaCl}, 0.01 \mathrm{M}$ Tris- $\mathrm{Cl}$ (pH 8), $0.01 \mathrm{M} \mathrm{Na}_{2}$ EDTA, and hydrolyzed with $80 \mu$ l of RNase digestion mix $(0.5 \mathrm{M} \mathrm{NaCl}, 20$ $\mathrm{mM}$ Tris- $\mathrm{Cl}$ at $\mathrm{pH} 8,1 \mathrm{~mm} \mathrm{MgCl}_{2}, 1 \mathrm{mg} / \mathrm{ml}$ of $E$. coli tRNA, $0.125 \mathrm{mg} / \mathrm{ml}$ of RNase A, $1200 \mathrm{U} / \mathrm{ml} \mathrm{RNase} \mathrm{Tl}$ ) at $37^{\circ} \mathrm{C}$ for 3 $\mathrm{hr}$. The reactions were stopped by the addition of $10 \mu \mathrm{l}$ of $0.12 \mathrm{M}$ $\mathrm{Na}_{2} \mathrm{EDTA}, 2 \% \mathrm{SDS}$, and $4 \mathrm{mg} / \mathrm{ml}$ of proteinase $\mathrm{K}$ and incubation for $15 \mathrm{~min}$ at $37^{\circ} \mathrm{C}$, followed by extraction with phenol $/$ chloroform/isoamyl alcohol (PCI, 40:1:1) and precipitation with $10 \mu \mathrm{g}$ of $E$. coli carrier RNA and 2 volumes of ethanol at $-20^{\circ} \mathrm{C}$ for $30 \mathrm{~min}$. Samples were separated by electrophoresis on a $12 \%$ polyacrylamide-urea, $0.5 \times$ TBE gel at $2000 \mathrm{~V}$ until the bromophenol blue tracking dye migrated $30 \mathrm{~cm}$ from the well and visualized by autoradiography with Kodak X-Omat film.

\section{Measurement of protein accumulation in vivo}

Cells were grown at $25^{\circ} \mathrm{C}$ in $10 \mathrm{ml}$ of YPED to a density of $1 \times 10^{6}$ to $2 \times 10^{6} \mathrm{cell} / \mathrm{ml}$ and labeled at $-60 \mathrm{~min}$ (prior to shift to $\left.35^{\circ} \mathrm{C}\right)$ by the addition of $100 \mu \mathrm{Ci}$ of $\left[{ }^{35} \mathrm{~S}\right]$ methionine $(1140$ $\mathrm{Ci} / \mathrm{mmole}, \mathrm{NEN}$ ). Aliquots of $0.5 \mathrm{ml}$ were withdrawn every 30 min (until 240 min postshift) and added to $0.5 \mathrm{ml} 10 \%$ TCA on ice. The mixture was boiled for $10 \mathrm{~min}$ and filtered through Whatman GFC filters and washed twice with $5 \mathrm{ml}$ of $5 \%$ TCA followed by $5 \mathrm{ml}$ of $90 \%$ ethanol. The filters were dried and the ${ }^{35} \mathrm{~S}$ incorporation was measured by scintillation counting.

\section{Preparation and analysis of yeast polysomes}

Cells were grown in $500 \mathrm{ml}$ of YEPD at $25^{\circ} \mathrm{C}$ to an $A_{600}$ of 2.0-3.0. Approximately $6 \times 10^{9}$ cells $/ \mathrm{ml}$ were harvested by centrifugation at $5000 \mathrm{~g}$ for $5 \mathrm{~min}$ at room temperature, and the remaining culture shifted to $35^{\circ} \mathrm{C}$ for $1 \mathrm{hr}$ followed by centrifugation as before. Pellets were resuspended in $5 \mathrm{ml}$ of sterile water at room temperature and mixed with $50 \mu$ l of cycloheximide $(10 \mathrm{mg} / \mathrm{ml})$, incubated on ice for $1 \mathrm{~min}$ and pelleted at $5000 \mathrm{~g}$ for $5 \mathrm{~min}$ at $4^{\circ} \mathrm{C}$. Pellets were resuspended on ice in $0.5 \mathrm{ml}$ of $1 \times$ breaking buffer $(20 \mathrm{~mm}$ HEPES-KOH at $\mathrm{pH} 7.4,2 \mathrm{~mm}$ $\mathrm{Mg}(\mathrm{OAc})_{2}, 0.1 \mathrm{M} \mathrm{KCl}, 14.4 \mathrm{mM}$ 2-mercaptoethanol, $0.1 \mathrm{mg} / \mathrm{ml}$ of 
cycloheximide). The cells were disrupted by eight cycles of vortexing for $30 \mathrm{sec}$ and $20 \mathrm{sec}$ chilling on ice in the presence of 400 $\mu l$ of sterile glass beads. The debris was pelleted by centrifugation at $5000 \mathrm{~g}$ for $8 \mathrm{~min}$ at $4^{\circ} \mathrm{C}$, and the supernatants were stored at $-70^{\circ} \mathrm{C}$. For polysome analysis, $25 A_{254}$ units were layered on top of $15-50 \%$ sucrose gradients prepared with $1 \times$ (low salt) polysome buffer [10 mM Tris-Cl at $\mathrm{pH} 7.4,70 \mathrm{~mm} \mathrm{NH} \mathrm{N}_{4} \mathrm{OAc}, 4$ $\left.\mathrm{mM} \mathrm{Mg}[\mathrm{OAc})_{2}\right]$. Polysomes were separated by ultracentrifugation at 40,000 rpm in an SW40Ti rotor (Beckman) for $2.5 \mathrm{hr}$ at $4^{\circ} \mathrm{C}$. Profiles were obtained by continuous $A_{254}$ measurement through an ISCO model UA-5 Absorbence/Fluorescence Monitor at a flow rate of $1 \mathrm{ml} / \mathrm{min}$, chart speed $60 \mathrm{~cm} / \mathrm{hr}$, and a 0.5 sensitivity level. Gradient fractions $(1 \mathrm{ml})$ were collected and stored in 3 volumes $95 \%$ ethanol at $-20^{\circ} \mathrm{C}$. The total amount of ribosomes sedimenting as polyribosomes was determined by cutting out the polyribosome portion of the gradient profiles and weighing them on an analytical balance.

\section{Extraction of RNA from polysome gradient fractions and RNA hybridization (Northern) analysis}

Gradient fractions precipitated in ethanol for at least $24 \mathrm{hr}$ were centrifuged for $20 \mathrm{~min}$ at $10,000 \mathrm{rpm}$ in a benchtop clinical centrifuge, supernatants discarded and pellets air dried at room temperature for $30 \mathrm{~min}$. The pellets were resuspended in $100 \mu \mathrm{l}$ of $10 \mathrm{mM}$ Tris- $\mathrm{Cl}(\mathrm{pH} 8.0)$, and $0.1 \mathrm{mM} \mathrm{Na}_{2}$ EDTA, transferred to new 1.5-ml Eppendorf tubes and digested in $0.012 \mathrm{M} \mathrm{Na}_{2}$ EDTA, $0.2 \%$ SDS, and $0.4 \mathrm{mg} / \mathrm{ml}$ of proteinase $\mathrm{K}$ for $15 \mathrm{~min}$ at $37^{\circ} \mathrm{C}$. The reactions were diluted to $400 \mu \mathrm{l}$ with $10 \mathrm{mM}$ Tris- $\mathrm{Cl} / \mathrm{pH}$ 8.0 ) and $0.1 \mathrm{mM} \mathrm{Na}{ }_{2}$ EDTA, extracted twice with $\mathrm{PCI}$, and precipitated on dry ice by the addition of $40 \mu \mathrm{l}$ of $3 \mathrm{M} \mathrm{KAc}$ and 800 $\mu \mathrm{l}$ of $95 \%$ ethanol.

Northern hybridization analyses were carried out as described previously (Patel and Butler 1992) with $30 \mu \mathrm{l}$ of polysome-extracted RNA in each lane. Antisense DNA probes were prepared by the random hexamer method according to manufacturer's instructions (Boehringer Mannheim) with the following genespecific templates: a $2.95-\mathrm{kb}$ HindIII-HindIII fragment containing the PGK1 gene from pDH8 (Mellor et al. 1983; kindly provided by A. Jacobson, University of Massachusetts Medical School, Boston), 3.4-kb SalI-HindIII fragment containing the $P A B 1$ gene from pYPA (Sachs et al. 1986; kindly provided by A. Jacobson) and a 2-kb fragment containing the TCM1 gene fom pT7-TCM1 -) (kindly provided by J. Warner, Albert Einstein College of Medicine, The Bronx, NY|. Conditions for hybridization were described previously (Patel and Butler 1992).

\section{Ribonuclease protection analysis}

Ribonuclease protection experiments were carried out with antisense riboprobes prepared in vitro from transcription templates constructed as follows: RT-PCR with a downstream oligo $(\mathrm{dT})_{17}$ containing a BamHI restriction site $\left(3^{\prime}-\mathrm{TTT}\right.$ TTTTTTTTTTTTTTCCTAGGTTTTT-5') and an upstream mRNA-specific primer containing an EcoRI restriction sequence (5'-GGAATTCCGGGTGGTTTCGTCCACTACGGTG-3' for TCM1; and 5'-GGAATTCCGCCACCTCAAGAGGTCTTCCC-3' for $P A B 1$ ) was carried out as described (Sadhale et al. 1991) except that the PCR annealing temperature was $55^{\circ} \mathrm{C}$. PCR products were hydrolyzed with EcoRI and BamHI restriction enzymes and cloned into the corresponding polylinker sites of pGEM $4 \mathrm{Z}$ (Promega). Riboprobes with specific activities of $1 \times 10^{8}$ to $2 \times 10^{8} \mathrm{cpm} / \mu \mathrm{g}$ were synthesized from pAPT3 linearized with PvuII for TCM1 and from pAPPB3 and pAPPB32 linearized with DdeI for the $P A B 1$ major site and $3^{\prime}$ distal site probes, respectively.

For determination of poly(A) tail length, ribonuclease diges- tion experiments were carried out with total yeast RNA (10 $\mu \mathrm{g}$ ) or polyribosome-associated RNA (5 $\mu$ l per fraction) in $30 \mu \mathrm{l}$ of $1 \times$ hybridization buffer $(40 \mathrm{~mm}$ PIPES at $\mathrm{pH} 6.5,0.4 \mathrm{M} \mathrm{NaCl}, 1$ mM EDTA, $20 \%$ deionized formamide) containing $5 \times 10^{5} \mathrm{cpm}$ of antisense riboprobe. The mixture was boiled for $4 \mathrm{~min}$ and transferred immediately to a $45^{\circ} \mathrm{C}$ heating block for $13-15 \mathrm{hr}$ hybridization. Following hybridization, $350 \mu \mathrm{l}$ of ribonuclease digestion buffer ( $10 \mathrm{~mm}$ Tris- $\mathrm{Cl}$ at $\mathrm{pH} 7.5,300 \mathrm{~mm} \mathrm{NaCl}, 5 \mathrm{~mm}$ EDTA) containing ribonuclease A $(1.4 \mu \mathrm{g} / \mathrm{ml}$, Sigma) and ribonuclease $\mathrm{Tl}(0.1 \mu \mathrm{g} / \mathrm{ml}$, U.S.Biochemical $)$ were added and the mixture incubated for $45 \mathrm{~min}$ at $30^{\circ} \mathrm{C}$, PCI extracted, and ethanol precipitated. The samples were separated by electrophoresis on an $8 \%$ polyacrylamide $/ 7 \mathrm{M}$ urea gel at $600 \mathrm{~V}(17-25 \mathrm{~mA})$ for $6 \mathrm{hr}$.

\section{Acknowledgments}

We thank Allan Jacobson, Alan Sachs, and John Warner for providing plasmids and technical advice; Allan Jacobson, Roy Parker, and Alan Sachs for stimulating discussions and Mark Dumont, Jay Greenberg, Allan Jacobson, Lasse Lindahl, Terry Platt, Jan Zengel, and the members of our laboratory for comments on the manuscript. This work was supported by a U.S. Public Health Service predoctoral training grant in microbial pathogenesis (5-T32-Al070362) to A.P. and National Science Foundation grants (DMB-9005602 and MCB-931664) awarded to J.S.B.

The publication costs of this article were defrayed in part by payment of page charges. This article must therefore be hereby marked "advertisement" in accordance with 18 USC section 1734 solely to indicate this fact.

\section{References}

Bachvrova, R.F. 1992. A maternal tail of poly(A): The long and the short of it. Cell 69: 895-897.

Baim, S.B. and F. Sherman. 1988. mRNA structures influencing translation in the yeast Saccharomyces cerevisiae. Mol. Cell. Biol. 8: 1591-1601.

Ballantine, J.E.M. and H.R. Woodland. 1985. Polyadenylation of histone mRNA in Xenopus oocytes and embryos. FEBS Lett. 180: 224-228.

Beelman, C.A. and R. Parker. 1994. Differential effects of translational inhibition in cis and in trans on the decay of the unstable yeast MFA2 mRNA. J. Biol. Chem. 269: 96879692.

Bergmann, J.E. and H.F. Lodish. 1979a. Translation of capped and uncapped vesicular stomatitis virus and retrovirus $\mathrm{mR}$ NAs. J. Biol. Chem. 254: 459-468.

- 1979b. A kinetic model of protein synthesis: Application to hemoglobin synthesis and translational control. $J$. Biol. Chem. 254: 11927-11937.

Bernstein, P., S.W. Peltz, and J. Ross. 1989. The poly(A)-poly(A)binding protein complex is a major determinant of mRNA stability in vitro. Mol. Cell. Biol. 9: 659-670.

Brawerman, G. 1981. The role of the poly(A) sequence in mammalian messenger RNA. CRC Crit. Rev. Biochem. 10: 1-39.

Burd, C.G., E.L. Matunis, and G. Dreyfuss. 1991. The multiple RNA-binding domains of the mRNA poly(A)-binding protein have different RNA-binding activities. Mol. Cell. Biol. 11: 3419-3424.

Decker, C.J. and R. Parker. 1993. A turnover pathway for both stable and unstable $m$ RNAs in yeast: Evidence for a requirement for deadenylation. Genes \& Dev. 7: 1632-1643.

Drummond, D.R., J. Armstrong, and A. Colman. 1985. The effect of capping and polyadenylation on the stability, movement and translation of synthetic mRNAs in X. laevis. Nu- 
cleic Acids Res. 13: 7375-7394.

Foiani, M., A.M. Cigan, C.J. Paddon, S. Harashima, and A.G. Hinnebusch. 1991. GCD2, a translational repressor of the GCN4 gene, has a general function in the initiation of protein synthesis in Saccharomyces cerevisiae. Mol. Cell. Biol. 11: 3203-3216.

Galili, A., E.E. Kawata, L.D. Smith, and B.A. Larkin. 1988. Role of $3^{\prime}$-poly(A) sequence in translational regulation of mRNAs in X. laevis oocytes. J. Biol. Chem. 263: 5764-5770.

Gallie, D.R. 1991. The cap and poly(A) function synergistically to regulate mRNA translational efficiency. Genes \& Dev. 5: 2108-2116.

Groner, B., N. Hynes, and S. Phillips. 1974. Length heterogeneity in the polyadenylic acid region of yeast mRNA. Biochemistry 13: 5378-5383.

Grossi da Sa, M-F., M. Standart, C. Martins de Sa, O. Akhayat, M. Huesca, and K. Scherrer. 1988. The poly(A)-binding protein facilitates in vitro translation of poly(A)-rich mRNA. Eur. J. Biochem. 176: 521-526.

Herrick, D., R. Parker, and A. Jacobson. 1990. Identification and comparison of stable and unstable mRNAs in Saccharomyces cerevisiae. Mol. Cell. Biol. 10: 2269-2284.

Hsu, C.L. and A. Stevens. 1993. Yeast cells lacking 5'-3' exoribonuclease 1 contain mRNA species that are poly $(A)$ deficient and partially lacking the $5^{\prime}$ cap structure. Mol. Cell. Biol. 13: 4826-4835.

Hynes, N.E. and S.L. Phillips. 1976. Turnover of polyadenylatecontaining sequences in Saccharomyces cerevisiae. I. Bacteriol. 125: 595-600.

Jackson, R.J. 1993. Cytoplasmic regulation of mRNA function: The importance of the 3' untranslated region. Cell 74: 9-14.

Jackson, R.J. and N. Standart. 1990. Do the poly(A) tail and 3' untranslated region control mRNA translation? Cell 62: 1524.

Jacobson, A. and M. Favreau. 1983. Possible involvement poly $(\mathrm{A})$ in protein synthesis. Nucleic Acids Res. 11: 63536368.

Larimer, F.W., C.L. Hsu, M.K. Maupin, and A. Stevens. 1992. Characterization of the XRN1 gene encoding a 5'-3' exoribonuclease: Sequence data and analysis of disparate protein and mRNA levels of gene disrupted yeast cells. Gene 120: $51-57$.

Laskey, R.A., A.D. Mills, J.B. Gurdon, and G.A. Partington. 1977. Protein synthesis in oocytes of Xenopus laevis is not regulated by the supply of messenger RNA. Cell 11:345351.

Lemay, G. and S. Milward. 1986. Inhibition of translation by free polyadenylaic acid: Differences in sensitivity among different mRNAs and possible involvement of an initiation factor. Arch. Biochem. Bioph. 249: 191-198.

Lowell, J.E., D.Z. Rudner, and A.B. Sachs. 1993. 3' UTR-dependent deadenylation by the yeast poly(A) nuclease. Genes \& Dev. 6: 2088-2099.

Martin, T.E. 1973. A simple general method to determine the proportion of active ribosomes in eukaryotic cells. Exp. Cell Res. 80: 496-498.

McGrew, L.L., E. Dworkin-Rastl, M.B. Dworkin, and J.D. Richter. 1989. Poly(A) elongation during Xenopus oocyte maturation is required for translational recruitment and is mediated by a short sequence element. Genes \& Dev. 3: 803-815.

Mellor, J., M.J. Dobson, N.A. Roberts, M.F. Tuite, J.S. Emtage, S. White, P.A. Lowe, T. Patel, A.J. Kingsman, and S.M. Kingsman. 1983. Efficient synthesis of enzymatically active calf chymosin in Saccharomyces cerevisiae. Gene 24: 1-14.

Muhlrad, D. and R. Parker. 1992. Mutations affecting stability and deadenylation of the yeast MFA2 transcript. Genes \&
Dev. 6: 2100-2111.

Munroe, D. and A Jacobson. 1990. mRNA poly(A) tail: A $3^{\prime}$ enhancer of translation initiation. Mol. Cell. Biol. 10: 34413455 .

Patel, D. and J.S. Butler. 1992. Conditional defect in mRNA 3' end processing caused by a mutation in the gene for poly $|A|$ polymerase. Mol. Cell. Biol. 12: 3297-3304.

Richter, J. 1991. Translational control during early development. BioEssays 13: 179-183.

Rosenthal, E.T., T.R. Tansey, and J.V. Ruderman. 1983. Sequence-specific adenylations and deadenylations accompany changes in the translation of maternal messenger RNA after fertilization of spisula oocytes. J. Mol. Biol. 166: 309-327.

Sachs, A.B. and R.W. Davis. 1989. The poly(A) binding protein is required for poly(A) shortening and $60 \mathrm{~S}$ ribosomal subunit dependent translation initiation. Cell 58: 857-867.

Sachs, A.B., M.W. Bond, and R.D. Kornberg. 1986. A single gene from yeast for both nuclear and cytoplasmic polyadenylatebinding proteins: Domain structure and expression. Cell 45: 827-835.

Sachs, A.B., R.W. Davis, and R.D. Kornberg. 1987. A single domain of yeast poly(A)-binding protein is necessary and sufficient for RNA binding and cell viability. Mol. Cell. Biol. 7: 3268-3276.

Sadhale, P.P., R. Sapolsky, J.S. Butler, R.W. Davis, and T. Platt. 1991. Polymerase chain reaction mapping of yeast GAL7 mRNA polyadenylation sites demonstrates that $3^{\prime}$ end processing in vitro faithfully reproduces the $3^{\prime}$ ends observed in vivo. Nucleic Acids Res. 19: 3683-3688.

Sheets, M.D., C.A. Fox, T. Hunt, G. Van de Woude, and M. Wickens. 1994. The $3^{\prime}$ untranslated regions of c-mos and cyclin mRNAs stimulate translation by regulating cytoplasmic polyadenylation. Genes \& Dev. 8: 926-938.

Storti, R.V., M.P. Scott, A. Rich, and M.L. Pardue. 1980. Translational control of protein synthesis in response to heat shock in D. Melanogaster cells. Cell 22: 825-834.

Varum, S.M. and W.M. Wormington. 1990. Deadenylation of maternal mRNAs during Xenopus oocyte maturation does not require specific cis-acting sequences: A default mechanism for translational control. Genes \& Dev. 4: 2270-2286.

Vassalli, J.-D., J. Huarte, D. Belin, P. Gubler, A. Vassalli, M.L. O'Connell, L.A. Parton, R.J. Rickles, and S. Strickland. 1989. Regulated polyadenylation controls mRNA translation during meiotic maturation of mouse oocytes. Genes \& Dev. 3: 2163-2171.

Wickens, M. 1992. Forward, backward, how much, when: Mechanisms of poly(A) addition and removal and their role in early development. Sem. Dev. Biol. 3: 399-412.

Wisdom, R. and W. Lee. 1991. The protein coding region of c-myc mRNA contains a sequence that specifies rapid mRNA turnover and induction by protein synthesis inhibitors. Genes \& Dev. 5: 232-243.

Yoon, H. and T.F. Donahue. 1992. The suil suppressor locus in Saccharomyces cerevisiae encodes a translation factor that functions during $t \mathrm{RNA}_{\mathrm{i}}^{\text {Met }}$ recognition of the start codon. Mol. Cell. Biol. 12: 248-260.

Yoon, H., S.P. Miller, E.K. Pabich, and T.F. Donahue. 1992. SSL1, a suppressor of a HIS4 5'-UTR stem-loop mutation, is essential for translation initiation and affects UV resistance in yeast. Genes \& Dev. 6: 2463-2477.

Zelus, B.D., D.H. Giebelhaus, D.W. Eib, K.A. Kenner, and R.T. Moon. 1989. Expression of the poly(A)-binding protein during development of $X$. laevis. Mol. Cell. Biol. 9: 2756-2760.

Zhong, T. and K.T. Arndt. 1993. The yeast SIS1 protein, a DnaJ homolog, is required for the initiation of translation. Cell 73: $1175-1186$. 


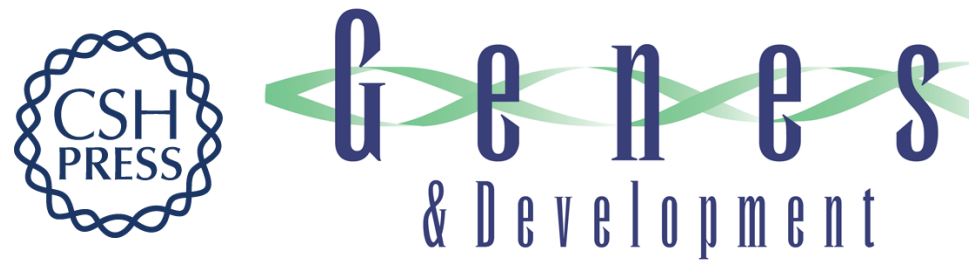

\section{Efficient translation of poly(A)-deficient mRNAs in Saccharomyces cerevisiae.}

A Proweller and S Butler

Genes Dev. 1994, 8:

Access the most recent version at doi:10.1101/gad.8.21.2629

References This article cites 48 articles, 24 of which can be accessed free at:

http://genesdev.cshlp.org/content/8/21/2629.full.html\#ref-list-1

License

Email Alerting

Service

Receive free email alerts when new articles cite this article - sign up in the box at the top right corner of the article or click here. 